\title{
Survivalist Entrepreneurship: An Income Generating Alternative for the Unemployed populace
}

\author{
Dr. Kgantsho Adeline Ranyane \\ University of the Free State, Business School, Bloemfontein, South Africa \\ ranyanek@webmail.co.za
}

\section{Doi:10.5901/mjss.2015.v6n4p301}

\begin{abstract}
A survivalist business is a type of business that is not considered to have a potential to generate income and to provide employment. The existence of such businesses is often crushed by literature as they are perceived to be businesses that are doomed for failure. Furthermore, governments around the world fail to support and recognize their existence within their structures. This paper highlights the ability of the survivalist businesses to generate jobs for family members as well as income that improves their socio-economic status. The sample in the study consisted of 100 survivalist entrepreneurs from the five districts of the Free State province, South Africa. Heterogeneity sampling was used in the absence of a sample frame. Using a $T$-Test, the monthly income of the participants was compared to the minimum wage rate set by the government to be earned by employees, stipulated in the South African minimum wages as set out in the basic conditions of employment act no. 11 of 2002 , particularly focusing on the amendments of sectoral determination 9: wholesale and retail sector in South Africa. A correlation matrix was utilized to investigate the reason for indulging into the survivalist businesses. Results indicated that the mean monthly income of the survivalist entrepreneurs was more than that stipulated in the basic conditions of employment act. Their educational qualifications were above the standard set by the existing literature. It was concluded that survivalist enterprises are an income and job generating alternative for the unemployed populace.
\end{abstract}

Keywords: survivalist businesses, job generation, income generation, Free State Province.

\section{Introduction}

South Africa is faced with socio-economic challenges that many African countries experience after being liberated. These include increasing poverty and unemployment rates. Unemployment has become an issue that also affects individuals who are equipped with the education and knowledge that was considered appropriate for formal labour markets in the past. This is made evident by the increasing statistics of the relatively well educated individuals, who are practising as survivalist entrepreneurs in the absence of formal employment in the Free State province and South Africa as a whole.

In the absence of recent statistics, the South African GEM report of 2011 indicated an increase in the numbers of survivalist entrepreneurs in South Africa, from $28.5 \%$ in 2006 to $34.8 \%$ in 2011.

Despite the existence of this growing population of survivalist entrepreneurs in South Africa, the government has failed to formally recognize their existence, as well as their potential to become income generating and job generating alternatives for many of the unemployed South Africans. This is made evident by the absence of a targeted policy approach to support and assist these businesses in order to become viable, recognized business entities.

\section{The Link between Unemployment, Poverty and Survivalist Businesses}

Throughout South Africa, job creation and development of sustainable businesses of any type remain the biggest challenge in all spheres. This challenge continues to be aggravated by the declining overall socio-economic profile and economic activities in South Africa that result in increasing unemployment rates. Concurrently the high unemployment rates hinder progress of poverty reduction programmes (Minford \& Mahambane, 2005). The declining levels of economic activity further lead to increasing dependency on self- employment as a survival mechanism. In this case selfemployment has become a buffer, providing families with an alternative source of income in South Africa.

Over the past two decades, the South African government managed to create different macro-economic strategies such as Growth, Employment and Redistribution Strategy (GEAR) and Accelerated shared growth initiative for South Africa (ASGISA) with the common aim of creating sustainable jobs in an attempt to reduce poverty levels and 
dependency on government for survival. Furthermore a proposal to strengthen the post apartheid small, medium and micro-enterprises (SMMEs) was formulated as early as 1995, in a form of a White paper on the National Strategy for the Development and Promotion of SMME's (Herrington et al., 2010).

The above mentioned White paper highlights SMMEs as an important vehicle in addressing the challenges of job creation, economic growth and equity. The White paper also confirms the presence of survivalist entrepreneurs amongst the SMME's of South Africa, and the urgent need for them to be assisted so as to improve their socio-economic conditions. Following this, was the formulation of institutional infrastructure, under the supervision of the Department of Trade and Industry (DTI). The aim being to address the objectives set out in the White paper in order to "create an enabling environment for SMME growth" throughout the country.

Although not represented in the acronym "SMME" the survivalist enterprises are lumped together with the microenterprises due to the similarities of not all but some of the obstacles they face. However unlike the opportunity driven micro-enterprises, survivalist entrepreneurs depend on their income for basic survival of their families. Their income serves as a cushion from poverty related issues. Furthermore they are unable to compete for resources due to their informality, thus creating an unfair scenario for the survivalist businesses.

Majority of the studies that have been carried out on the informal sector businesses explain that those caught up in poverty resort to the informal sector as a survival strategy. A survey of the key factors shaping micro-enterprise in urban West Africa indicated poverty as the overriding factor that shaped the micro enterprise sector in the area of study. This is because the response to poverty was the primary motivation for the micro entrepreneurs in the study (Roy \& Wheeler, 2006).

Akingunola \& Onayemi (2010) indicate that the dropping formal sector employment and the increasing population in Nigeria, forced more Nigerians to turn to informal sector in an attempt to survive. The dropping formal sector employment brought about by economic decline, led to increasing competition within the labour markets. Consequently this pushed those at the bottom of the employment queue to self employment as survivalist entrepreneurs in an attempt to survive.

The Statistics SA (2011) report indicated that $70.4 \%$ of South Africans were living below the poverty line of R620 per capita per month. The results were later supported in an independent survey by Afro barometer (2012), which revealed that South Africa was amongst the African countries which were failing to reduce the effects of poverty.

Although South Africa has a strong GDP, it is unable to benefit the people at the grassroots level, thus creating an unequal distribution of income, indicated by the current Gini-coefficient of 0.7 . This simply indicates that the rich become richer, while the poor become poorer, thus increasing the poverty gap between the rich and the poor. According to Fine et al (2008) the poorest $20 \%$ of South Africans are reported to receiving $1.6 \%$ of total income while the richest $20 \%$ benefit from $70 \%$ of the total income.

The high unemployment rates as well as relatively high levels of poverty force the poor into survivalist entrepreneurship, in order to buffer the effects of poverty and unemployment. Therefore there is a link between the formation of survivalist businesses and the poverty and unemployment rates.

\section{Research Methods}

\subsection{Participants}

The study comprised of 100 participants from the Free State province of South Africa. The participants were survivalist entrepreneurs from the five districts of the Free State province. A non-probability method of sampling, heterogeneity sampling, was utilized as there was no sampling frame. Face to face interviews, using a structured questionnaire, were conducted with the owners of survivalist businesses who were found on sight on the day of the visit.

\subsection{Procedure}

The researcher investigated the income made by each survivalist entrepreneur who participated in the study. This income was then compared with the South African minimum wages as set out in the basic conditions of employment act no. 11 of 2002, particularly focusing on the amendments of sectoral determination 9: wholesale and retail sector in South Africa, using a T-Test.

The number of years in running the business was also compared with that documented in existing literature using a T-Test. A Pearson correlation matrix was utilized to investigate various reasons/motivations that push the survivalist owner into starting the business. 


\subsection{Data collection}

The questionnaire consisted of mainly close-ended questions, which offered the respondent a selection of possible responses. The close-ended questions were made up of mainly five point likert scale (summated) questions as well as dichotomous questions. Likert scale questions consist of a collection of statements, from which the participants had to indicate the degree to which they agree or disagree on, while dichotomous questions had only two possible answers or response categories (Peterson, 2000). The above type of questions were the preferred type as they were suitable for the type of data being collected which included nominal, ordinal, interval as well as ratio.

\section{Results}

To explore whether survivalist enterprises are income generating alternatives for the unemployed populace, a one sample t-test was used to test the assumption of the null hypothesis that the sample mean income earned by survivalists is equal to the minimum wage rate set by the government to be earned by employees, working as shop assistants, stipulated in the South African minimum wages as set out in the basic conditions of employment act no. 11 of 2002, particularly focusing on the amendments of sectoral determination 9: wholesale and retail sector in South Africa, $\left(H_{0}: \mu_{1}=\right.$ R2,254.03). The null hypothesis was tested against the alternative hypothesis which states that the sample mean income earned by survivalist entrepreneurs does not equal to the minimum wage rate set by the government to be earned by employees in the wholesale and retail sector $\left(\mathrm{H} 0: \mu_{1} \neq \mathrm{R} 2,254.03\right)$. The empirical results tabulated in table 1 show that the $p$-value associated with the $t$-test is less than the 0.05 level of significance $(t=4.581, p<0.000)$.

Table 1: Mean monthly income earned by survivalist entrepreneurs in the Free State province, South Africa.

\begin{tabular}{|l|c|c|c|c|}
\hline \multicolumn{1}{|c|}{ Variable } & Observation & Mean & Std. Err. & Std. Dev. \\
\hline Mean monthly Income earned by survivalist entrepreneurs (Rand) & 100 & 2,633 & 82.720 & 827.196 \\
\hline \multicolumn{3}{|c|}{ Minimum wage rate (MWR) $=2,254.03$} \\
\hline Null hypothesis & \multicolumn{3}{|c|}{4.581} \\
\hline$t$-statistic & \multicolumn{3}{|c|}{99} \\
\hline Degrees of freedom & \multicolumn{3}{|c|}{} \\
\hline Alternative hypothesis (Ha) & $M W R<2254.03$ & $M W R=2254.03$ & $M W R>2254.03$ \\
\hline & $\operatorname{Pr}(T<t)=1.000$ & $\operatorname{Pr}(T>t)=0.000$ & $\operatorname{Pr}(|T|>|t|)=0.000$ \\
\hline
\end{tabular}

The calculations as set out in table 1 suggest that there is supportive evidence that the mean monthly income earned by survivalist entrepreneurs is different from the hypothesized government minimum wage rate of R2, 254.03. Thus, the null hypothesis is rejected and the alternate hypothesis remains valid. This implies that the mean income earned by survivalist entrepreneurs significantly differs from the minimum wage. In this context the survivalists actually earn more money (R2, 633) on a monthly basis as compared to those employed in the wholesale and retail sector of South Africa as shop assistants. This argument can ardently be explained by the number of years people have been indulging in this kind of businesses. For instance, more than $80 \%$ of the respondents (of whom women accounted for $48 \%$ ) had more than a year's experience in their enterprises (see table 2).

Table 2: T test on years of experience between males and females.

\begin{tabular}{l|c|c|}
\hline \multicolumn{2}{|c|}{ Period in current business (years) } & Frequency \\
\hline \multirow{2}{*}{ More than 1 year } & Male & 48 \\
\cline { 2 - 3 } & Female & 35 \\
\hline \multirow{2}{*}{ Less than 1 year } & Male & 4 \\
\cline { 2 - 3 } & Female & 13 \\
\hline \multicolumn{2}{|c|}{} & Male \\
\hline \multirow{2}{*}{ Mean period in business (years) } & Female & 2.51 \\
\hline \multirow{2}{*}{ t-test } & & 1.94 \\
\hline \multirow{2}{*}{ * } & & $(0.05)$ \\
\hline
\end{tabular}


Table 2 implies that such enterprises generate an income of some sort which individuals use to sustain their families. Otherwise, many of the respondents would have closed business within the shortest time possible in a bid to look for other avenues of acquiring an income. Furthermore, the observed results may also be explained basing on reasons for which these individuals embark on running survivalist enterprises. Table 3 of correlation matrix results below suggests that there exists supportive evidence for the existence of a positive $(p=0.011)$ relationship between the need to avoid unemployment and poverty, and the need to survive.

Table 3: Pearson's correlation matrix between the various reasons for indulging into survivalist enterprises.

\begin{tabular}{|l|c|c|c|c|c|c|c|c|}
\hline \multicolumn{1}{|c|}{ Variable ( $\mathbf{n = 1 0 0 )}$} & Mean & Standard error & A & B & C & D & E & F \\
\hline A To be an independent / own boss (Freedom) & 3.48 & 1.38 & 1 & & & & \\
\hline B To avoid unemployment and poverty & 4.05 & 1.06 & $\begin{array}{c}-0.532^{*} \\
(0.000)\end{array}$ & 1 & & & \\
\hline C Advice from other people & 1.90 & 0.86 & $\begin{array}{c}-0.194^{* *} \\
(0.053)\end{array}$ & $\begin{array}{c}-0.041 \\
(0.687)\end{array}$ & 1 & & \\
\hline D The need (necessity) to survive & 2.18 & 1.07 & $\begin{array}{c}-0.044 \\
(0.667)\end{array}$ & $\begin{array}{c}-0.253^{* *} \\
(0.011)\end{array}$ & $\begin{array}{c}-0.139 \\
(0.168)\end{array}$ & 1 & \\
\hline E Recognition of an opportunity & 3.40 & 1.36 & $\begin{array}{c}-0.461^{*} \\
(0.000)\end{array}$ & $\begin{array}{c}-0.021 \\
(0.838)\end{array}$ & $\begin{array}{c}-0.215^{* *} \\
(0.032)\end{array}$ & $\begin{array}{c}-0.480^{*} \\
(0.000)\end{array}$ & 1 & 1 \\
\hline F How long have you been in current business (years) & 3.17 & 1.69 & $\begin{array}{c}-0.018 \\
(0.856)\end{array}$ & $\begin{array}{c}0.022 \\
(0.829)\end{array}$ & $\begin{array}{c}-0.198^{* *} \\
(0.048)\end{array}$ & $\begin{array}{c}-0.148 \\
(0.141)\end{array}$ & $\begin{array}{c}0.231^{* *} \\
(0.021)\end{array}$ & 1 \\
\hline
\end{tabular}

${ }^{*}$ and ${ }^{* *}$ denote that correlation is significant at the all levels and 0.05 level, respectively (2-tailed).

Table 3 implies that the majority get involved in doing such business to generate an income by which to survive. Otherwise, if such business enterprises were not income generating, many would see no reason to venture their meagre resources into them. Looking at the educational perspective, descriptive statistics further suggest that these enterprises are indeed income generating given that even participants with qualification that allow them to have a formal job actively operate such enterprises.

Table 4 shows the educational level of respondents who ventured into survivalist business so as to avoid unemployment and poverty. Concurrently table 4 indicates that lower educational status is no longer a characteristic that is only attributed to the survivalist entrepreneurs, who are characterized by literature as school-drop outs.

Table 4: Educational level.

\begin{tabular}{|c|c|c|}
\hline Education level & Frequency $(\mathbf{n = 1 0 0 )}$ & Percentage $(\%)$ \\
\hline Matric & 53 & 53 \\
\hline School Drop-out & 29 & 29 \\
\hline National Certificate & 18 & 18 \\
\hline & & 100 \\
\hline
\end{tabular}

Within the South African employment framework, a matric and a National Certificate graduate, meet the minimum formal employment requirements. However, a good proportion of these graduates are grounded in operating survivalist enterprises.

This argument may be attributable to the fact that survivalists earn tax free incomes as compared to their counterparts with the same educational qualifications. Furthermore it proves that survivalist businesses are an income generating alternative for individuals who fail to find formal employment.

Literature highlights survivalist entrepreneurs as business activities that do not generate employment, and therefore are not assisting with reducing the unemployment rates. However with unemployment on a vast rise in South Africa, job generating alternatives are essential in dealing with the rising numbers of job losses. A survivalist enterprise automatically serves as a job generating alternative for at least the owner or individual who is running it.

The exploration of survivalist enterprises as a job generating alternative for unemployed people was based on two indicators: the educational level of the survivalist entrepreneurs, and the period spent in running the business. As earlier mentioned, analytical results reveal that more than $80 \%$ of the respondents had actually spent more than a year in operating their business and that the educational background of the individuals venturing into survivalist business did not play a role in their decision. It was rather the envisaged opportunities, particularly income generation that such 
businesses would provide, in order to avoid unemployment and poverty, and most importantly to be able to provide for their families.

That being mentioned, survivalist enterprises may be perceived as job generating entities in a sense that they bring on a number of actors/ players along the entire value chain of a specific business. Despite the fact that all actors along the value chain get a small payment at the end of the day, that particular survivalist enterprise will have contributed towards enabling its causal labourers to earn an income.

\section{Conclusion}

The study proved that survivalist enterprises are both income and job generating alternatives for the unemployed people. Despite being ignored by the government, these businesses are currently generating both income and jobs for those who are running them.

The above facts which have been proven by this study contrast the reviewed literature, which highlights the survivalist enterprises as a business that is unable to either generate income or employment.

Despite the misinterpretation by literature, this type of business allows at the least the owner to have a job, which means an opportunity to have a source of income, in order to support their families and to cushion them from the adverse results of poverty and unemployment.

The South African GEM (2005) Report found that, in South Africa, almost a third of

survivalist enterprises created 1.6 jobs on average per enterprise. Hence the gradual increase in the number of individuals who opt to become survivalist entrepreneurs. Naude and Havenga (2007) also indicate that there is an opportunity to make income and to have a job in this type of businesses.

The concept of being able to generate a job for an individual owner should have been recognized by existing literature. However it is not, perhaps in order to discredit survivalist enterprises as a form of business. Concurrently, the presence of different theories on the formation of survivalist enterprises could have possibly influenced the literature as many viewed the survivalist enterprises as either an old informal practice, that originated in the previous era and is disappearing (modernization perspective).

However the results of the study points out that the survivalist businesses are more prone to be influenced by a combination of mainly the structuralism perspective, which views the survivalist business formation as growing rather than contracting, due to the emergence of the deregulation (neo-liberal) open world economy, that affects the current labour standards. The neo-liberal perspective simply implies that the survivalist entrepreneur would choose his business as an alternative to the formal business. In other words, they are pushed into their business as an alternative to formal employment due to the shrinking formal employment.

The mean monthly income earned by survivalist entrepreneurs, as depicted in table 1, R2633.00 per month, is more than the average minimum wage rate of R2254.03, which is stipulated in the basic conditions of employment act no. 11 of 2002, when focusing on the amendments of the sectoral determination 9 for wholesale and retail sector in South Africa (Department of Labour, SA, 2014).

Furthermore the Pearson correlation matrix on various reasons for indulging into survivalist enterprises, as depicted in table 3 concludes to indicate that majority of survivalist entrepreneurs are generating income by which they survive, and by which they are able to avoid and/or cushion themselves and their families from poverty and/ or unemployment.

The findings mentioned above are supported in a study conducted in South Africa by Rolfe et al. (2010). The study investigated the viability of informal micro-enterprises in South Africa. It proved that the survivalist businesses allowed the owner to reach a minimal standard of living. The average salary of the participants in the study was close to the urban minimum wage of R1067.00 and above the R866.00 minimum wage set for rural areas.

The findings of both the current study and the study highlighted above contradict the existing literature, which refer to survivalist entrepreneurs as living below the set poverty rate levels of their respective countries and unable to have a minimal standard of living.

Therefore survivalist business entities are an income and job generating alternative for the unemployed people, and should be recognized and assisted by the South African Government inorder to reduce dependency on government by the unemployed populace, as well as to improve the socio-economic conditions of this populace. This will in the long run benefit families as well as their local economy by contributing towards poverty and unemployment reduction as well as contributing towards their GDP going forward. 


\section{References}

Afro barometer surveys (2012). The Quality of Democracy and Governance in 20 African Countries, 2008-2009. Accessed from http://www.icpsr.umich.edu/icpsrweb/ICPSR/studies/33701/version/1 [January 03, 2013]

Akingunola R.O., Onayemi S.O. (2010). The role of informal finance in the development of women micro-businesses in Nigeria. A case study of Ogun and Oyo States. International Journal of Academic Research, 2(5), 331-338.

Department of Labour, SA (2013). Minimum Wage Review. Accessed from www.labour.gov.za. [February 11, 2013]

Fine B., Asham S. \& Newman S. (2010) The Crisis in South Africa: Neoliberalism, Financialization and Uneven and Combined Development. Socialist Register, 47: 174-195.

Global Entrepreneurship Monitor (2005). GEM 2005 South African Report. Accessed from www.gemconsortium.org [January 03, 2011]

Global Entrepreneurship Monitor (2011).GEM 2011 Sub-Saharan Africa Regional Report Policy Insights. Accessed from www.gemconsortium.org [January 03, 2011]

Herrington M., Kew J., Kew P. (2010) Tracking Entrepreneurship in South Africa: A GEM Perspective. Accessed from http://bbbee. typepad.com/paul_janisch/files/GEM [August 14, 2010]

Minford P \& Mahambane V (2005) South Africa's Labour Market towards 2015. Economic intelligence series. Sandton: Johannesburg: CHASMA (Chamber of Commerce and Industry South Africa).

Naude W.A. \& Havenga J.J.D. (2007). An overview of African Entrepreneurship and Small Business Research.United Kingdom: Edwad Elgar.

Peterson R.A (2000). Constructing effective questionnaires. SAGE Publications, Inc.

Rolfe R., Woodward D., Ligthelm A. \& Guimaraes P. (2010). The Viability of Informal Micro-enterprise in South Africa. Presented at the Conference on "Entrepreneurship in Africa" Whitman School of Management, Syracuse University, Syracuse, New York, April 1$3,2010$.

Roy M., Wheeler D. (2006). A survey of micro-enterprise in urban West Africa: drivers shaping the sector. Development in Practice $16(5), 452-464$

Statistics South Africa (2011). Statistics South Africa, Annual report 2012-2013. Accessed from www.gov.za/documents/download [february 20, 2013] 